\title{
Effects of hydric deficiency on gas exchange parameters and metabolism of Eucalyptus grandis clones
}

\author{
Renata B. S. Coscolin ${ }^{1}$, Fernando Broetto ${ }^{1 *}$, José A. Marchese ${ }^{2}$, \\ Marco C. Campohermoso ${ }^{3}$, Marcos V. Paladini'
}

${ }^{1}$ Department of Chemistry and Biochemistry, Institute of Biosciences, São Paulo State University (Unesp), 18618000, Botucatu, São Paulo, Brazil;

${ }^{2}$ Laboratory of Plant Physiology and Biochemistry, Department of Agronomy, Federal Technological University of Paraná (UTFPR), 85503-390, Pato Branco, Paraná, Brazil;

${ }^{3}$ Departamento de Riego. Centro de Edafología y Biología Aplicada del Segura (CSIC) P.0. Box 164, E-30100 Murcia, Spain.

* Corresponding author: Tel/Fax 00551438116255 e-mail: broetto@ibb.unesp.br Received: 14 July 2011; Accepted: 30 January 2012

\section{ABSTRACT}

The metabolic effects caused by hydric deficiency (HD) on Eucalyptus grandis clones were assessed by an experiment where plants were cultivated in four blocks. The first was the control block, normally irrigated, whereas the other three blocks were submitted to cycles of hydric deficiency. Analysis of photosynthetic efficiency, enzymatic activity of antioxidant response system, level of pigments and $L$-proline concentration were performed to evaluate the HD effects. Results showed that HD altered some parameters related to photosynthetic activity, pigments accumulation, proline and enzymatic activity. Clone 433 of $E$. grandis presented higher response ability to $\mathrm{HD}$.

Keywords: Enzymes, eucalypt, hydric deficiency, photosynthesis.

\section{INTRODUCTION}

Hydric deficiency is the consequence of a continuous or transitory drought that impairs growth of plants due to the decrease of water potential, stomata conductance, photosynthesis and assimilation of $\mathrm{N}$ by the plant. Leaf area affects crop yield positively or negatively, and depends on the efficiency of water use by the plant, then crop yield may be affected by hydric deficiency due to a decrease of leaf area (Rodrigues et al., 1998). Plants have the ability to perform tolerance mechanisms to adapt themselves and face drought periods that vary according to genotype (Chaves et al., 2002;
Shvaleva et al., 2006; Costa and Silva et al., 2009). Among these mechanisms, alterations of morphophysiology, physiology and some metabolic traits are included (Volaire et al., 1998; Marchese et al,. 2010), enabling the plants react to this environmental stress by controlling transpiration and inhibiting growth (Chaves et al., 2003). Prolonged drought may induce the production of reactive oxygen species (ROS) at cellular level causing deleterious effects to the cell membranes system. The process of hydric deficiency in tissues also induce the production of some metabolites to help the cells preserve structural and functional integrity of their membranes (Marchese et al., 2010), specially L-proline, glycine betaine and some sugars (Smirnoff, 1998). 
Antioxidant defenses of forest species have been the scope of interest related to environmental stress (Polle and Rennenberg, 1992), however few studies have considered the activity of antioxidant response system of eucalypt at hydric deficiency conditions (Osawa et al., 1992; Costa and Silva et al., 2009).

Most ROS in plant cells are generated by reduction of molecular oxygen $\left(\mathrm{O}_{2}\right)$ followed by successive dismutations of superoxide anions $\left(\mathrm{O}_{2}{ }^{-}\right)$and hydrogen peroxide $\left(\mathrm{H}_{2} \mathrm{O}_{2}\right)$, which can evolve to hydroxyl radical $\left(\mathrm{OH}^{-}\right)$through iron catalyzed reactions. When plants are exposed to stressing environments (low temperatures, hydric deficiency, high intensity of light and others), the accumulation of ROS increase causing damages to cells due to the oxidation of constituents, especially at cell membrane (Asada, 1999; Broetto et al., 2002; Marchese et al., 2008). The enzymes that are involved in the ROS dismutation system are generally superoxide dismutase (SOD; EC 1.15.1.1), catalase (CAT; EC 1.11.1.6), ascorbate peroxidase (APX), monodehydroascorbate reductase (MDAR), dehydroascorbate reductase (DHAR) and glutathione reductase (GR). High expression of SOD enzyme was observed in several species of plants when submitted to stressing factors, during induction of antioxidative response system (ARS).

Superoxide dismutase is one of the main enzymes of ARS that catalyses the dismutation of superoxide radicals to $\mathrm{H}_{2} \mathrm{O}_{2}$. Another important enzyme of ARS is CAT, that can decompose $\mathrm{H}_{2} \mathrm{O}_{2}$ to form $\mathrm{H}_{2} \mathrm{O}$ into the peroxisomes during photorespiration (Gerbling et al., 1984). Alteration of CAT activity is expected as a response to salinity, high intensity of light, cold and transition of C3-CAM photosynthetic path. According to Kalir and Pljakoff-Mayber (1981) CAT activity of Halimione portulacoides leaves decreases after salt treatment because salt causes structural alterations of enzymes as demonstrated by in vitro experiments. Degradation of CAT was also reported in several species, as a response to light intensity (Engel, 1986; Broetto et al., 2002; Marchese et al., 2008). This study was performed to assess the effects of hydric deficiency $(\mathrm{HD})$ on gas exchange and metabolism of $E$. grandis clones.

\section{MATERIAL AND METHODS}

The ability of tolerance to hydric deficiency was evaluated with $E$. grandis species (clones 433 and 105) at approximately 90 days of cultivation, acquired from Eucatex Florestal enterprise (Botucatu, SP-Brazil) and selected according to sensibility (clone 433) and resistance (clone 105) to HD.
Substrate for essays was collected from soil plot patrulha located in experimental area from FCA/UNESP, Botucatu (São Paulo, Brazil). Soil samples were addressed to Soil Lab of FCA/ UNESP and results were used to determine the scheme for liming and fertilization application and to supply the nutritional requirements based on recommendations by Raij et al. (1997). Later, soil was dried and aliquots were collected to determine humidity and calculate the levels of water in each block (field capacity and submitted to stress). From these data, a table was assembled to control irrigation, considering integral plant mass + dry soil weight $+\%$ of water $(-0.01 \mathrm{MPa}=26 \%$ of humidity and $-1.5 \mathrm{MPa}=19 \%$ ). The following expression was used to calculate the $\%$ of soil humidity: $\mathrm{U}=$ (weight of humid soil - weight of dry soil) $\times 100$ / weight of dry soil. Seedlings were transplanted into $8 \mathrm{~L}$ capacity pots, kept for adaptation in tunnel greenhouse and irrigated regularly, during five weeks to achieve optimum growth stage. After this period, the first cycle of HD began and plants from each evaluated clone (433 and 105) were divided into four blocks with 15 plants each and submitted to treatments: periods of HD and control. Period of HD was defined according to the methodology of checking the weight of pots associated to a table assembled from control block data. Therefore, blocks were divided as a function of field capacity (FC) and submitted to stress (HD) observed by daily control of every plant located into blocks. The experimental design used was complete randomized, recommended for greenhouse essays (Banzatto and Kronka, 1989). Comparison between means of treatments submitted to $\mathrm{HD}$ and means of control was performed by $t$-Student test, at $5 \%$ of significance, using SYSTAT 5 software program.

Four evaluations of gas exchange were performed after HD cycle began to determine liquid photosynthetic rate, stomata conductance, transpiration and internal concentration of $\mathrm{CO}_{2}$, measured by open gas exchange system equipped with an infrared gas analyzer (IRGA) model LI-6400XT (LI-COR, Lincoln, Nebrasca - USA). The initial evaluation was made at the initial phase, when irrigation of plants submitted to HD (first cycle of HD) was interrupted; the first evaluation was made after four days; and the second after 11 days, at the most severe phase of HD. After this photosynthetic evaluation, all plants at $\mathrm{HD}$ were rehydrated, and the second cycle of $\mathrm{HD}$ began. The third (and last) photosynthetic evaluation was made after seven days from the beginning of the second $\mathrm{HD}$ cycle to verify the effect of rehydration on plants submitted to one HD cycle.

Parallel to photosynthetic evaluations, completely expanded leaves were collected for biochemical analysis. 
Leaves were frozen in liquid $\mathrm{N}$, grounded until a fine dust was gathered and kept in an ultrafreezer at $-80^{\circ} \mathrm{C}$. Samples were analyzed to determine the activity of the enzymes catalase (CAT, EC 1.11.1.6) and superoxide dismutase (SOD, ED 1.15.1.1) according to methodology described by Peixoto et al. (1999). In order to obtain raw extract, tissue samples (300 $\mathrm{mg}$ ) were resuspended in potassium phosphate buffer $(0.1$ $\mathrm{M}, \mathrm{pH}$ 6.8), and supernatant from centrifugation (10 min at $10,000 \times g$ ) was collected and stored in at $-80^{\circ} \mathrm{C}$. Soluble protein concentration in extracts was determined in triplicates, using the method described by Bradford (1976), with bovine serum albumin (BSA) as protein standard. L-proline level was determined with colorimeter test using the method described by Bates et al. (1973), thus raw extract $(1.0 \mathrm{~mL})$ was mixed with acid ninhydrin $(1.0 \mathrm{~mL})$ and glacial acetic acid $(1.0 \mathrm{~mL})$, heated for 60 minutes, cooled and the readings were performed at $520 \mathrm{~nm}$ with L-proline P.A. pattern line as reference.

Absorbance measures of the raw extract were made for analysis of pigments chlorophyll and anthocyanin according to method described by Lee et al. (1987). Chlorophyll and anthocyanin were extracted from foliar discs kept in dimethylformamide (DMF) and in acidified DMF, respectively, and the readings for chlorophyll were performed at $480,646.8$ and $663.8 \mathrm{~nm}$ and for anthocyanin at 525,654 and $666 \mathrm{~nm}$.

\section{RESULTS}

Clone 433 presented higher photosynthetic rate $(\sim 25 \mu \mathrm{mol}$ $\mathrm{m}^{-2} \mathrm{~s}^{-1}$ ) at normal conditions (Table 1). Liquid photosynthesis values decreased according to applied $\mathrm{HD}$ for both clones with results around $2 \mu \mathrm{mol} \mathrm{m} \mathrm{m}^{-2} \mathrm{~s}^{-1}$ since irrigation was interrupted until the third observation (11 days after de beginning of treatments). Control treatment of both clones, also presented a decrease tendency of photosynthetic activity, but with less intensity. After rehydration of plants and one week after the beginning of the second cycle of $\mathrm{HD}$, the fourth evaluation was made and the results showed that photosynthetic activity began the process of recovering the plants to the levels observed at the second evaluation. This effect was observed for both clones, and clone 433 presented better yield.

Table 1. Gas exchange analysis $(\mathrm{n}=4)$ : photosynthesis $(\mathrm{A})$, estomata conductance $\left(\mathrm{g}_{s}\right)$, transpiration and internal concentration of $\mathrm{CO}_{2}$ of $E$. grandis (clones 433 and 105) leaves submitted to hydric deficiency (HD).

\begin{tabular}{|c|c|c|c|c|c|c|c|c|}
\hline $\begin{array}{l}\text { E. grandis } \\
\text { Clone }\end{array}$ & \multicolumn{2}{|c|}{$\begin{array}{c}\text { Photosynthesis } \\
\mathrm{A}\left(\mu \mathrm{mol} \mathrm{CO} \mathrm{m}_{2}^{-2} \mathrm{~s}^{-1}\right)\end{array}$} & \multicolumn{2}{|c|}{$\begin{array}{c}\text { Conductance } \\
\mathrm{g}_{\mathrm{s}}\left(\mathrm{mol} \mathrm{H}_{2} \mathrm{O} \mathrm{m}^{-2} \mathrm{~s}^{-1}\right)\end{array}$} & \multicolumn{2}{|c|}{$\begin{array}{c}\text { Transpiration } \\
\mathrm{T}\left(\mathrm{mg} \mathrm{H}_{2} \mathrm{O} \mathrm{m}^{-2} \mathrm{~s}^{-1}\right) \\
\end{array}$} & \multicolumn{2}{|c|}{$\begin{array}{c}\text { Int. Conc. of CO } \\
\mathrm{Ci}\left(\mu \mathrm{mol} \mathrm{CO} \mathrm{mol}_{2}^{-1}\right)\end{array}$} \\
\hline Initial evaluation & $\mathrm{HD}$ & Control & $\mathrm{HD}$ & Control & $\mathrm{HD}$ & Control & $\mathrm{HD}$ & Control \\
\hline 433 & - & $25.68 \mathrm{a}$ & - & $2.17 \mathrm{a}$ & - & $3.26 \mathrm{a}$ & - & $298.00 \mathrm{a}$ \\
\hline 105 & - & $22.15 \mathrm{~b}$ & - & $1.47 \mathrm{~b}$ & - & $3.30 \mathrm{a}$ & - & $305.20 \mathrm{a}$ \\
\hline C.V. / MSD & \multicolumn{2}{|c|}{$4.59 / 1.11$} & \multicolumn{2}{|c|}{$13.75 / 0.68$} & \multicolumn{2}{|c|}{$6.09 / 0.2$} & \multicolumn{2}{|c|}{$2.58 / 7.87$} \\
\hline $1^{\text {st }}$ Evaluation & $\mathrm{HD}$ & Control & $\mathrm{HD}$ & Control & $\mathrm{HD}$ & Control & $\mathrm{HD}$ & Control \\
\hline 433 & $14.35 \mathrm{Ab}$ & $22.05 \mathrm{Aa}$ & $0.41 \mathrm{Ab}$ & $0.94 \mathrm{Aa}$ & $3.05 \mathrm{Ab}$ & $4.62 \mathrm{Aa}$ & $235.87 \mathrm{Aa}$ & $295.40 \mathrm{Aa}$ \\
\hline 105 & $11.72 \mathrm{Ab}$ & $17.25 \mathrm{Ba}$ & $0.37 \mathrm{Aa}$ & $0.63 \mathrm{Ba}$ & $2.20 \mathrm{Ab}$ & $4.13 \mathrm{Aa}$ & $191.05 \mathrm{Ab}$ & $296.80 \mathrm{Aa}$ \\
\hline C.V./ MSD & \multicolumn{2}{|c|}{$17.66 / 3.3$} & \multicolumn{2}{|c|}{$15.84 / 0.21$} & \multicolumn{2}{|c|}{$22.74 / 1.03$} & \multicolumn{2}{|c|}{$23.39 / 72.09$} \\
\hline $2^{\text {nd }}$ Evaluation & $\mathrm{HD}$ & Control & $\mathrm{HD}$ & Control & $\mathrm{HD}$ & Control & $\mathrm{HD}$ & Control \\
\hline 433 & $2.51 \mathrm{Ab}$ & $6.18 \mathrm{Aa}$ & $0.06 \mathrm{Ab}$ & $0.18 \mathrm{Aa}$ & $0.56 \mathrm{Ab}$ & $1.45 \mathrm{Aa}$ & $269.95 \mathrm{Aa}$ & $300.20 \mathrm{Aa}$ \\
\hline 105 & $2.26 \mathrm{Ab}$ & $5.39 \mathrm{Aa}$ & $0.05 \mathrm{Aa}$ & $0.10 \mathrm{Ba}$ & $0.55 \mathrm{Ab}$ & $1.00 \mathrm{Ba}$ & $275.71 \mathrm{Aa}$ & $254.80 \mathrm{Ba}$ \\
\hline C.V./MSD & \multicolumn{2}{|c|}{$24.74 / 1.23$} & \multicolumn{2}{|c|}{$6.19 / 0.09$} & \multicolumn{2}{|c|}{$11.68 / 0.41$} & \multicolumn{2}{|c|}{$17.27 / 58.18$} \\
\hline $3^{\text {rd }}$ Evaluation & $\mathrm{HD}$ & Control & $\mathrm{HD}$ & Control & $\mathrm{HD}$ & Control & $\mathrm{HD}$ & Control \\
\hline 433 & $12.68 \mathrm{Ab}$ & $16.37 \mathrm{Aa}$ & $0.10 \mathrm{Aa}$ & $0.12 \mathrm{Aa}$ & $1.38 \mathrm{Ab}$ & $1.82 \mathrm{Aa}$ & $228.07 \mathrm{Ab}$ & $106.33 \mathrm{Ab}$ \\
\hline 105 & $11.63 \mathrm{Ab}$ & $13.47 \mathrm{Ba}$ & $0.06 \mathrm{Bb}$ & $0.09 \mathrm{Ba}$ & $0.99 \mathrm{Bb}$ & $1.42 \mathrm{Aa}$ & $142.92 \mathrm{Aa}$ & $97.53 \mathrm{Ab}$ \\
\hline C.V. / MSD & \multicolumn{2}{|c|}{$11.24 / 1.4$} & \multicolumn{2}{|c|}{$2.47 / 0.02$} & \multicolumn{2}{|c|}{$2.57 / 0.2$} & \multicolumn{2}{|c|}{$27.11 / 71.78$} \\
\hline
\end{tabular}

Means followed by same letter, uppercase in lines and lowercase in columns, do not differ by Student $t$-test at $5 \%$ of significance. C.V. $=$ coefficient of variation (\%); $\mathrm{MSD}=$ Minimum significant differences.

Stomata conductance $\left(\mathrm{g}_{s}\right)$ was affected by HD for both clones and by sampling periods of parameters. The effective $\mathrm{g}_{s}$ of clone 433, was higher than the observed for clone 105. Rehydration of plants did not revert immediately the process of stomata closure. Apparently, recovery of stomata opening ability depends on more complex intracellular adjustments than the observed for photosynthetic activity. Transpiration rates indicate that the decrease of values for 
clone 433 was caused by HD together with stomata closure events. This effect was similar for clone 105, although control plants presented transpiration rate higher than the clone 433. The ability of recovering $g_{s}$ of clone 433 was higher at the third evaluation after rehydration, keeping gas exchange rate higher.

Internal concentration of $\mathrm{CO}_{2}$ presented low variation for both clones until rehydration of plants ( $3^{\text {rd }}$ evaluation). After that, a decrease of $\mathrm{CO}_{2}$ internal concentration of clone 433 control plants was observed whereas the concentration for this clone in treatment blocks were maintained with little variation. This effect was observed for clone 105 plants in the last observation, with more accentuated drop of the control plants.

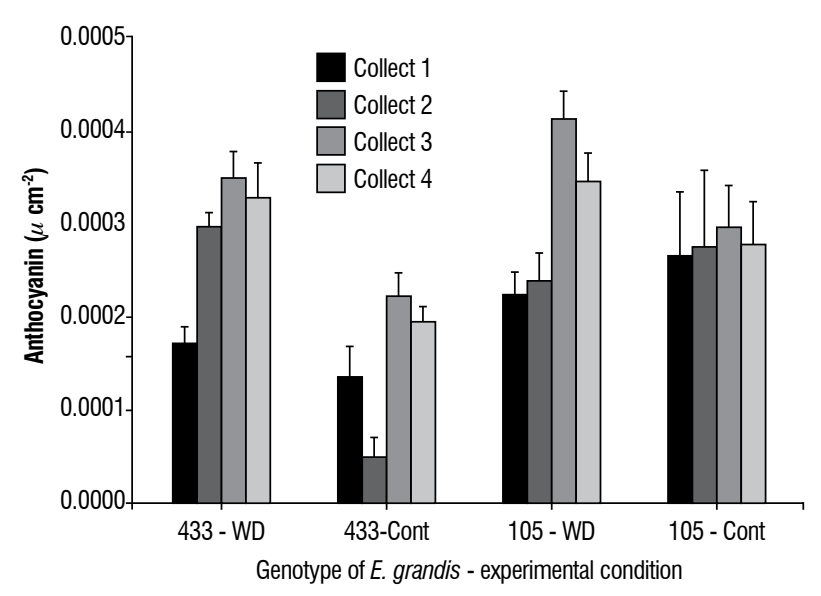

Figure 1. Leaf anthocyanin concentration of $E$. grandis (clones 433 and 105) kept under different treatments of hydric deficiency. Samples were collected at 4, 11 and 18 days after the beginning of treatments. Collection 1 represents initial anthocyanin concentration before interruption of irrigation and Collection 4, evaluates anthocyanin concentration after rehydration of plants. Values represent mean \pm SE $(n=6)$.

L-proline accumulation (Figure 3) was observed in E. grandis leaves from clone 433 (when compared to control plants) submitted to HD and after approximately 2 weeks from the beginning of stress (collection 3), which was repeated at a lesser extent in collection 4 after rehydration of plants. Proline accumulation was not so evident in leaves of the clone 105, although a difference can be observed when compared to control block. L-proline accumulation is directly related to the
Anthocyanin concentration presented a slight increase (more intense for clone 105) when plants were submitted to $\mathrm{HD}$, mainly after nine days from the beginning of stress (Figure 1). Plants from control blocks of both clones presented few variations of anthocyanin concentration and, apparently, rehydration of plants (collection 4) was not able to restore anthocyanin concentration.

Chlorophyll concentration of clone 105 was influenced after three weeks of $\mathrm{HD}$ and the interruption of stress was not enough to restore the decreased chlorophyll concentration for this clone. The opposite could be observed for clone 433 that, apparently, have different characteristics for tolerance to hydric deficiency than clone 105 for this parameter and level of anthocyanin (Figure 1 and 2).

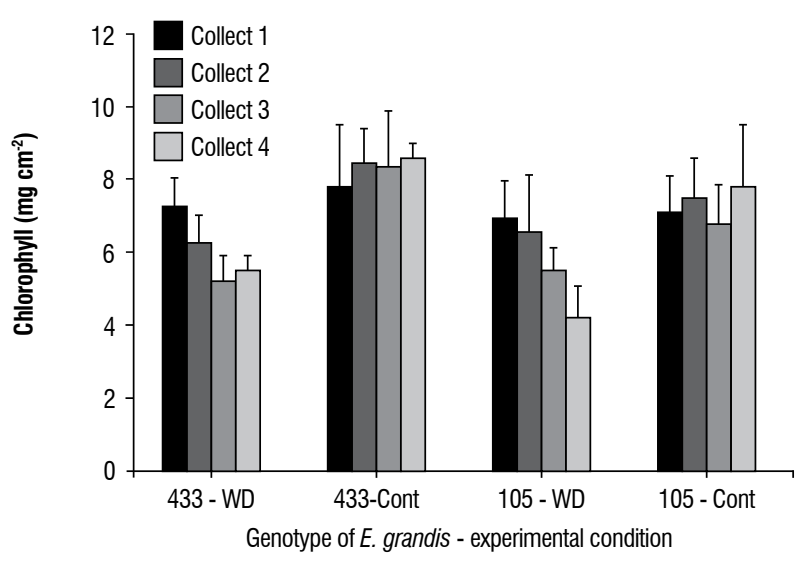

Figure 2. Total chlorophyll concentration (a, b) of $E$. grandis (clones 433 and 105) kept under different HD periods. Samples were collected at 4, 11 and 18 days after the beginning of treatment. Collection 1 represents initial chlorophyll concentration, before irrigation was interrupted, and Collection 4 evaluates total chlorophyll concentration after rehydration of plants. Values represent mean \pm SE $(n=6)$.

maintenance of internal water potential of plant cells, in order to keep the potential gradient needed for water absorption.

A longer stress period induced the SOD activity of the clone 433 (Figure 4). Control plants also presented this response but at lower degree. However, this response was not observed in the clone 105 evidencing, as discussed earlier, the higher response ability of clone 433 . 


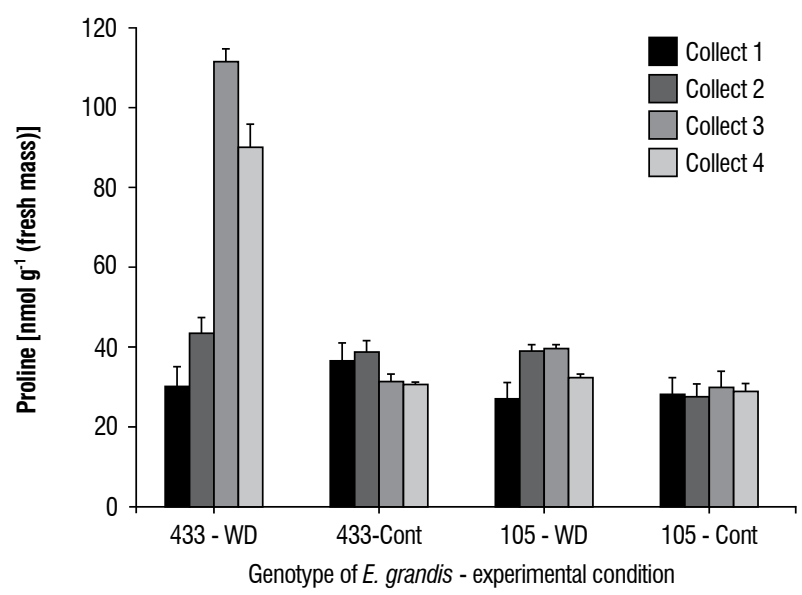

Figure 3. Leaf L-proline concentration of $E$. grandis (clones 433 and 105) kept under different hydric deficiency (HD) periods. Samples were collected at 4,11 and 18 days after the beginning of treatments. Collection 1 represents the initial concentration of L-proline, before irrigation was interrupted, and collection 4 evaluates L-proline concentration one week after rehydration of plants. Values represent the mean $\pm S E(n=6)$.

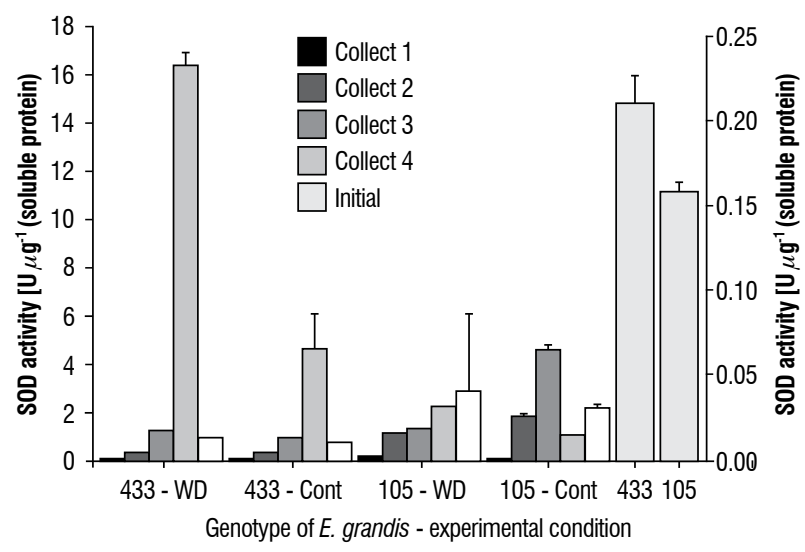

Figure 4. SOD activity of $E$. grandis (clones 433 and 105) kept under different hydric deficiency (HD) periods. Collection 1 represents the initial activity of SOD (represented in $Y$ axis at the right side of the figure, in different scale), and Collection 5 evaluates the SOD activity one week after rehydration of plants. Values represent the mean $\pm S E(n=6)$.

Moderate HD stress induced CAT activity in clones 433 and 105 (Figure 5). However, CAT activity decreased when the clone 105 was submitted to the most severe phase of stress and return to increase when plants were rehydrated (collection 5). Due to the heterogeneity of results, CAT should not be used to evaluate the effects of $\mathrm{HD}$ on $E$. grandis. On the other hand, the increase of CAT activity might be related to the increase of cell respiration rate, as a function of an alteration of metabolic paths related to vegetative development.

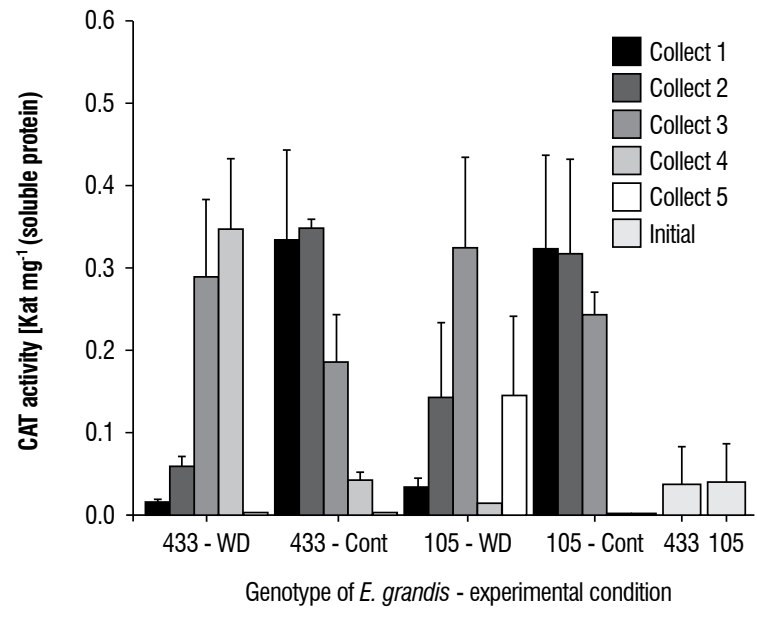

Figure 5. Leaf CAT activity of $E$. grandis (clones 433 and 105) kept under different Hydric deficiency (HD) periods. Collection 1 represents the initial CAT activity, and Collection 5 evaluates the CAT activity one week after rehydration of plants. Values represent the mean $\pm S E(n=6)$.

\section{DISCUSSION}

Obtained results for gas exchange parameters seems to be similar to that previously found by Herms and Mattson (1992), Kramer and Boyer (1995), Larcher (1995) and Leonardo (2003). These authors reported that progressive stress at moderate or severe level affects photosynthetic ability of plants. The most immediate consequence of $\mathrm{HD}$ would be an interruption of $\mathrm{CO}_{2}$ supply with losses in dry matter accumulation, vital for vegetative development. Therefore, low stress and foliar expansion rarely affects liquid photosynthesis rate although foliar expansion is more important than turgidity alterations to affect photosynthesis (Costa, 2001).

Photosynthetic efficiency can eventually increase when $\mathrm{HD}$ is established because the partial closure of stomata affects transpiration more than $\mathrm{CO}_{2}$ absorption. However, as stress become more severe, the relation between $\mathrm{CO}_{2}$ absorbed at photosynthesis and water steam lost in transpiration decreases and as consequence the inhibition of leaf metabolism increases (Taiz, 2004).

Cultivation of plants under moderate conditions of $\mathrm{HD}$ may reduce the photosynthetic assimilation of $\mathrm{CO}_{2}$ due to an increase of resistance to $\mathrm{CO}_{2}$ diffusion, as a consequence of stomata closure (Rey et al., 1999). However, severe HD may favor the ROS formation that causes injuries to plants by oxidizing photosynthetic pigments, membrane lipids, 
proteins and nucleic acids. Therefore decreases in the levels of chlorophyll or protein may be a symptom of oxidative stress as have been verified in plants under HD (Smirnoff, 1995).

Egertand Tevini (2002) did not verify significantalterations on levels of chlorophyll, proteins and antioxidant components when plants of Allium schoenoprosum were submitted to $\mathrm{HD}$ which, according to those authors, indicates an absence of oxidative stress. Despite degradation of photosynthetic pigments due to oxidative damage is considered to be an ordinary symptom of plants exposed to severe $\mathrm{HD}$, plants can protect themselves through biosynthesis of antioxidant components (carotene, ascorbate, $\alpha$-tocopherol, glutathione and flavonoides) and increase of antioxidant enzymes levels (peroxidase, superoxide dismutase and catalase). Carvalho (2003), studied the relation of water availability in soil as a function of Artemisia growth, and concluded that chlorophyll concentration (SPAD) tends to decrease when plants are submitted to $\mathrm{HD}$, indicating the beginning of foliar senescence.

L-proline accumulation of plants submitted to HD has been broadly reported in literature. Important reports from Hare and Cress (1997) and Stewart et al. (1977) described the proline accumulation phenomena and its relation to the increase of glutamate flux as well as to the decrease of proline catabolism.

One of the reactions involved in the proline biosynthesis is mediated by pirroline-5-carboxilase reductase ( $\mathrm{P} 5 \mathrm{C}$ ), which activity is directly influenced by variations on osmotic potential of cytosol (Williamson and Slocum, 1992). Thus, the exposure of plants to HD may unleash the increase of P5C activity, inducing proline accumulation in tissues. Delauney and Verma (1993) suggested that this amino acid accumulation is an important stress adaptation to the osmotic adjustment. Other functions commonly attributed to proline are its function as a cell structure-stabilizer and as a dismutation agent of free radicals (Saradhi et al., 1995).

Several authors suggest that proline accumulation occurs as a function of protein hydrolysis that increases in stress situations (Torello and Rice, 1986; Thomas et al., 1992; Leonardo, 2003; Tonin, 2005; Carvalho et al., 2005). Some researchers believe that free amino acids, like proline, are cell protectors of plants submitted to stress, acting as N reserve, osmotic solutes and hydrophobic protectors of enzymes and other cell structures (Somal and Yapa, 1998). Marur et al. (1994) suggested that the increase of free amino acids levels could contribute on plant tolerance to HD by increasing osmotic potential. However, the accumulation of proline and other solutes into cell vacuoles (osmotic adjustment) can decrease the osmotic potential of plants or be characterized as nitrogen reservoir, mainly for synthesis of specific enzymes.

Therefore, L-proline accumulation mechanisms in stress situations are not yet clearly understood. Decrease of protein levels, according to Marur et al. (1994), could be reflected on decrease of synthesis or increase of degradation, resulting in high levels of free amino acids. According to Madan et al. (1995), higher level of proline may happen also due to a higher activity of enzymes involved in proline biosynthesis (ornithine aminotransferase and pyrroline-5-carboxylaxe reductase) in as much due to inhibition of a degrading enzyme, the proline oxidase.

Possibly, the effect of HD on stomata closure and decrease of photosynthetic ability of plants may have contributed for the increase of SOD activity. The hindrance of gas exchange function is known for this enzymatic class, and may accelerate the formation of ROS at the photosynthetic apparatus that, in this case, worked as inducers of SOD. According to Miszalski et al. (1998) and Broetto et al. (2002), SOD increases activity when plants are submitted to many environmental stresses, including drought, high or low temperatures, soil salinity, high light intensity, and several biotic stress. However, high or low ability of antioxidative response also depends of intrinsic features of species.

Other authors, working with different environment stress reported similar results (Leonardo, 2003; Zhujun et al., 2004; Rosa et al., 2005). They suggested that SOD activity may be interpreted as biochemical marker for reaction of plants in environment stress situations, presenting antioxidative functions, acting at the dismutation of ROS.

However, SOD activity is also required in normal situations for dismutation of ROS resulted from the sugar metabolism of mitochondria, therefore, the use of SOD as a biochemical marker of any stress must be performed taking into account all the possible oscillations of this enzyme activity in normal conditions.

Hydrogen peroxide $\left(\mathrm{H}_{2} \mathrm{O}_{2}\right)$ produced during photorespiration in peroxisomes may be decomposed by CAT or ascorbate peroxidase and reduced by water $\left(\mathrm{H}_{2} \mathrm{O}\right)$. 
SOD may also be responsible, as known, by the increase of $\mathrm{H}_{2} \mathrm{O}_{2}$ level in cells due the conversion of superoxide radicals $\left(0^{-2}\right)$. Zhujun et al. (2004) and Tonin (2005), reported an increase in CAT activity when plants were submitted to saline stress. Some authors affirmed that a set of stressing environment conditions may interfere, causing alterations in protein structure of the enzyme or decreasing the activity of hydrolysis. Such alterations in catalase activity may occur as a response to salinity, high light intensity, temperature and other stressing events, with decrease of catalase activity (Feierabend and Engel, 1986; Broetto et al., 2002).

Obtained results allow the conclusion that HD altered all parameters evaluated by gas exchange, mainly those related to photosynthetic rate and stomata closure. Rehydration of plants restored, in part, the photosynthetic functions. Evaluating these physiological parameters, clone 433 of $E$. grandis apparently is the most efficient to overcome the effects of HD. Accumulation of pigments (chlorophyll and anthocyanin) and the level of proline of the two studied genotypes were altered by HD. However, clone 433 is the most efficient, compared to clone 105, in proline accumulation what can represent an important osmoprotective advantage to cope with the HD effects. SOD activity can be used as a good indicator of response ability of plants when free radicals are present, an expected situation in $\mathrm{HD}$ conditions, mainly because of its effect upon photosynthesis during stomata closure.

Acknowledgements: This research received financial support from the FAPESP (Fundação de Amparo à Pesquisa do Estado de São Paulo, Brazil). Coscolin, R.B.S was supported by FAPESP Grant \# 04238-8.

\section{REFERENCES}

Asada, K. 1999. The water-water cycle in chloroplasts: Scavenging of active oxygens and dissipation of excess photons. Annu. Rev. Plant Physiol. Plant Mol. Biol. 50:601-639.

Banzatto, D.A. and S.N. Kronka. 1989. Experimentação Agrícola. Jaboticabal: FUNEP. 247p.

Bates, L.S., R.P. Waldern and I.D. Teare. 1973. Rapid determination of free proline for water stress studies. Plant Soil. 39:205-07.

Bradford, M.M. 1976. A rapid and sensitive method for the quantitation of microgram quantities of protein utilizing the principle of dye-binding. Anal. Biochem. 72:248-254.

Broetto, F., U. Lüttge and R. Ratajczak. 2002. Influence of light intensity and salt-treatment on mode of photosynthesis and enzymes of the antioxidative response system of Mesembryanthemum crystallinum. Functional Plant Biol. 29:13-23
Carvalho, L.M., V.W.D. Casali, M.A. Souza, L.C.A. Barbosa and P.R. Cecon. 2005. Crescimento, teor de partenolídeo e de prolina em plantas de Tanacetum parthenium (L.) Schultz-Bip crescidas em substrato com diferentes teores de umidade. Acta Scientiarum 27:151-157.

Chaves, M.M., J.P. Maroco and J.S. Pereira. 2003. Understanding plant response to drought- from genes to the whole plant. Functional Plant Biol. 30:239-264.

Chaves, M.M., J.S. Pereira, J.P. Maroco, M.L. Rodrigues, C.P.P. Ricardo, M.L. Osorio, I. Carvalho, T. Faria and C. Pinheiro. 2002. How plants cope with water stress in the field. Photosynthesis and growth. Ann. Bot. 89:907-916.

Costa e Silva, F., A. Shvaleva, F. Broetto, M.F. Ortuño, M.L. Rodrigues, M.H. Almeida, M.M. Chaves and J.S. Pereira. 2009. Acclimation to short-term low temperatures in two Eucalyptus globulus clones with contrasting drought resistance. Tree Physiol. 29:77-86.

Costa, R.A. 2001. As relações hídricas em plantas vasculares. Universidade de Évora. Portugal. Available at: http://www.angelfire.com.

Delauney, A. and D. Verma. 1993. Proline biosynthesis and osmoregulation in plants. Plant J. 4:215-223.

Egert, M. and M. Tevini. 2002. Influence of drought on some physiological parameters symptomatic for oxidative stress in leaves of chives (Allium schoenoprasum). Environ. Exp. Bot. 48:43-49.

Feierabend, J. and S. Engel. 1986. Photoinactivation of catalase in vitro and in leaves. Arch. Biochem. Biophys. 251:630-638.

Gerbling, K.P., G.J. Kelly, K.H. Fisher and E. Latzko. 1984. Partial purification and properties of soluble ascorbate peroxidase from pea leaves. J. Plant Physiol. 115:59-67.

Hare, P.D. and W.A. Cress. 1997. Metabolic implications of stress-induced proline accumulation in plants. Plant Growth Regul 21:79-102.

Herms, D.A. and W.J. Mattson. 1992. The dilemma of plants: to grow or defend. Quart. Rev. Biol. 67:283-335.

Kalir, A. and A. Poljakoff-Mayber. 1981. Changes in activity of malate dehydrogenase, catalase, peroxidase and superoxide dismutase in leaves of Halimione portulacoides (L.) Aellen exposed to high sodium chloride concentrations. Ann. Bot. 47:75-85.

Kramer, P.J. and J.S. Boyer. 1995. Water relations of plants and soils. London: Academic Press. 495p.

Larcher, W. 1995. Physiological plant ecology. $3^{\text {rd }}$. ed. Berlin: Springer. 506p.

Lee, D.W., S. Bremmeier and A.P. Smith. 1987. The selective advantage of anthocyanins in developing leaves of mango and cacao. Biotropica. 19:4049.

Leonardo, M. 2003. Estresse salino induzido em plantas de pimentão (Capsicum annuum L.) e seus efeitos sobre a produtividade e parâmetros agronômicos e bioquímicos. 100p Dissertation (Agronomy-Irrigation and Drainage) Botucatu, UNESP/FCA.

Madan, S., H.S. Nainawatee, R.K. Jain and J.B. Chowdhury. 1995. Proline and proline metabolizing enzymes in in-vitro selected NaCl-tolerant Brassica juncea L. under salt stress. Ann. Bot. 76:51-57.

Marchese, J.A., R.S. Mattana, L.C. Ming, F. Broetto, P.F. Vendramini and R.M. Moraes. 2008. Irradiance stress responses of gas Exchange and antioxidant enzyme contents in pariparoba (Pothomorphe umbellata L. Miq.). Photosynthetica, 46:501-505.

Marchese, J.A., J.F.S. Ferreira, V.L.G. Rehder and 0. Rodrigues. 2010. Hydric deficiency effect on the accumulation of biomass and artemisinin in annual wormwood (Artemisia annua L., Asteraceae). Braz. J. Plant Physiol. 22:1-9.

Marur, C.J., L. Sodek and A.C. Magalhes. 1994. Free amino acids in leaves of cotton plants under water deficit. Rev. Bras. Fisiol. Veg. 6:103-108.

Miszalski, Z., I. Slesak, E. Niewiadonska, R. Baczek-Kwinta, U. Lüttge and R. Ratajczak. 1998. Subcellular localization and stress response of superoxide dismutase isoforms from leaves in the $\mathrm{C}_{3}$-CAM intermediate halophyte Mesembryanthemum crystallinum L. Plant Cell Environ. 21:169-179. 
Osawa, T., S. Ramarathnam, S. Kawakishi and M. Namiki. 1992. Antioxidative defense systems generated by phenolic plant constituents. In Phenolic Compounds in Food and their Effects on Health II. Eds. M.T. Huang, C.T. Ho, C.Y. Lee. Antioxidants and Cancer Prevention. ACS Symp. Ser. 507:122-134.

Peixoto, P.H.P., J. Cambraia, R. Sant'anna, P.R. Mosquin and M.A. Moreira. 1999. Aluminium effects on lipid peroxidation and on the activities of enzymes of oxidative metabolism in sorghum. Revista Brasileira de Fisiologia Vegetal 11:137-143.

Polle, A. and H. Rennenberg. 1992. Field studies on Norway spruce trees at high altitudes. II. Defense systems against oxidative stress in needles. New Phytol. 121:635-640.

Raij, B.van, H. Cantarella, J.A. Guaggio and A.M.C. Furlani. 1996. Recomendações de adubação e calagem para o estado de São Paulo. $2^{\text {nd }}$ ed. Campinas: Instituto Agronômico de Campinas. 285p.

Rey, P., G. Pruvot, B. Gillet and G. Peltier. 1999. Molecular characterization of two chloroplastic proteins induced by Hydric deficiency in Solanum tuberosum L. plants: involvement in the response to oxidative stress. In Plant responses to environmental stress. Eds. M.F. Smallwood, C.M. Calvert, D.J. Bowles. Oxford: BIOS Scientific Publishers. 224p.

Rodrigues, O., J.C.B. Lhamby, A.D. Didonet J.A. Marchese and C. Scipioni. 1998. Efeito da deficiência hídrica na produção do trigo. Pesquisa Agropec Brasil 33:839-846.

Rosa, S.D.V.F., E.V.R. Von Pinho, E.S.N. Vieira and R.D. Veiga. 2005. Enzimas removedoras de radicais livres e proteínas lea associadas à tolerância de sementes de milho à alta temperatura de secagem. Rev Bras Sementes 27:91-101

Saradhi, P.P, Alia, S. Arora and K.V.S.K. Prasad. 1995. Proline accumulates in plants exposed to UV radiation and protects them against UV induced peroxidation. Biochem Biophys. Res. Commun. 209:1-5.

Shvaleva, A.L., F. Costa e Silva, E. Breia, L. Jouve, J.F. Hausman, M.H. Almeida, J.P. Maroco, M.L. Rodrigues, J.S. Pereira and M.M. Chaves. 2006. Metabolic responses to water deficit in two Eucalyptus globulus clones with contrasting drought sensitivity. Tree Physiol. 26:239-248.

Smirnoff, N. 1995. Metabolic flexibility in relation to the environment. In: Environment and plant metabolism: flexibility and acclimation. Oxford: Bios Scientific publishers.
Smirnoff, N. 1998. Plant resistance to environmental stresss. Curr. Opin. Biotechnol 9:214-219.

Somal, T.L.C. and P.A.J. Yapa. 1998. Accumulation of praline in cowpea under nutrient, drought, and saline stresses. J. Plant Nutr. 21:2465-2473.

Stewart, C.R., S.F. Boggess, D. Aspinall and L.G. Paleg. 1977. Inhibition of proline oxidation by water stress. Plant Physiol. 59:930-932.

Taiz, L. and E. Zeiger. 2004. Fisiologia vegetal. Trad. Santarém, E.R. [et al.]. $3^{\text {rd }}$. Porto Alegre: Artmed. $719 \mathrm{p}$.

Thomas, J.C., R.L. Armond and H.J. Bohnert. 1992. Influence of $\mathrm{NaCl}$ on growth, proline and phospheonolpyruvate carboxylase levels in Mesembryanthemum crystallinum suspension cultures. Plant Physiol. 98:626-631.

Tonin, F.B. 2005. Atividade de enzimas antioxidativas e absorção de silício em plantas de pimentão submetidas a estresse salino. 93 p. Dissertation (Agronomy-Horticulture) Botucatu, UNESP/FCA.

Torello, W.A. and L.A. Rice. 1986. Effect of $\mathrm{NaCl}$ stress on Proline and cation accumulation in salt sensitive and tolerant turfgrasses. Plant Soil 93:241-27.

Volaire, F., H. Thomas and F. Lelievre. 1998. Survival and recovery of perennial forage grasses under prolonged Mediterranean drought. I. Growth, death, water relations and solute content in herbage and stubbe. New Phytol. 140:439-449.

Williamson, C. L. and R. D. Slocum. 1992. Molecular cloning and evidence for osmoregulation of the A1-pyrroline-5-carboxylatereductase (proC) gene in pea (Pisum sativum L.). Plant Physiol. 100:1464-1470.

Zhujun, Z., W. Guoquiang, L. Juan, Q. Qiongqiu and Y. Jingquan. 2004. Silicon alleviates salt stress and increases antioxidant enzymes activity in leaves of salt-stressed cucumber (Cucumis sativus L.). Plant Sci. 167:527-533. 